\title{
Why do Third Sector Employees Intend to Remain or Leave their Workplace?
}

\author{
I Kirsikka Selander' \\ PhD student, University of Jyväskylä, Finland
}

I Petri Ruuskanen

University Lecturer, University of Jyväskylä, Finland

\begin{abstract}
Third sector employees have claimed to enjoy high job satisfaction and low turnover intentions because their work is considered intrinsically rewarding. Employees have strong motivation for public service and they consider the organization's goals as their own. This makes work meaningful and thus reduces turnover intentions. Changes in the third sector institutional environment, however, have intensified the working environment. This probably undermines job quality and thus increases turnover intentions. The analysis conducted among Finnish third sector employees showed that third sector employees report more turnover intentions than their counterparts in the public or private sector. This is mostly because of low job quality. Motivation for public service was not enough to retain employees in the organization if their values were not congruent with those of the employer organization. Thus, connection between public service motivation and turnover intentions is dependent on the organizational context. More important than employees' desire to help others is their sharing of the employer organization's values and that the organization provides high job quality.
\end{abstract}

\section{KEY WORDS}

Job quality / public service motivation / third sector / turnover intentions

DOI

10.19154/njwls.v6i2.4973

\section{Introduction}

$\mathrm{n}$ the third sector literature, it has often been suggested that employees working in nonprofit organizations enjoy greater job satisfaction. According to the argument, this is due to intrinsic work benefits related to nonprofit work. It has also been assumed that employees enter and stay in third sector organizations (TSOs) because they want to serve the community and promote organizational goals, even if it requires self-sacrifice (Benz 2005; Borzaga and Tortia 2006; Hansmann 1980; Rose-Ackerman 1996). It has been assumed that this kind of 'public service motivation' or intrinsic motivation to serve the community makes work more meaningful and thus reduces employees' turnover intentions (Perry and Wise 1990).

\footnotetext{
${ }^{1}$ kiira.k.selander@jyu.fi
} 
According to previous studies conducted in the USA and Korea, however, TSOs face challenges in hiring and retaining employees. This is mainly due to low pay satisfaction and lack of advancement opportunities (e.g., Ban et al. 2003; Brown and Yoshioka 2003; Kang et al. 2015; Kim and Lee 2007). In Italy, Becchetti et al. (2014) however, found that a large share of those employees who voluntarily moved from the for-profit sector to the nonprofit sector had higher job satisfaction after the change. They also perceived significantly higher time flexibility, improved relationships with stakeholders, and closer conformity to educational skills in their new jobs.

In the Nordic countries, studies on third sector paid employees are rare. This is mainly due to the fact that TSOs in Nordic countries have traditionally employed fewer paid workers than their counterparts in other developed countries (Salamon et al. 1999), and thus the interest on the third sector working life has been limited. Simultaneously, however, there has been a major institutional change in the third sector of the Nordic countries. The importance of civil society in the field of welfare services has increased as public deficits compelled public sector authorities to seek more efficient means to provide welfare services. As a consequence of this, the Nordic TSOs have increasingly shifted from social movement organizations to welfare service providers, and the number of paid employees has increased substantially (Ruuskanen et al. 2016; Sivesind and Selle 2010; Wijkström 2011).

It has been suggested that the role of TSOs as coproducers of public services may lead to bargaining of job quality in terms of deskilling and insecurity (Cunningham and James 2009; Shragge et al. 2001). On the other hand, public service motivation may attract and keep employees in the TSOs. Thus, in the Nordic third sector, there may be two contradictory forces related to employees' turnover intentions. In this article we first ask whether third sector employees in Finland are more committed to their jobs than others in terms of turnover intentions. Second, we ask why third sector employees intend to stay in or leave their workplace.

The article is organized as follows. The next section provides a short overview of institutional changes affecting third sector employment in the Nordic context. Thereafter, we discuss the interrelated concepts of turnover intentions, public service motivation, and job quality. In the following section, empirical data and measures for the study are described. The results section, firstly, compares turnover intentions between third, public, and private sector employees in Finland. Secondly, it responds to the question about the main factors that influence turnover intentions among third sector employees.

\section{Change of Third Sector Employment in Nordic Countries}

The role that TSOs play in the provision of welfare services has historically varied in different welfare regimes (e.g., Kendall 2009; Salamon et al. 2003). In the 'Nordic model' the third sector was not widely engaged in providing services. Instead TSOs have engaged mostly in expressive functions. In other words, they have acted as 'vehicles for the expression of political, social and recreational interests' (Salamon and Anheier 1998, p. 229; see also Alapuro and Stenius 2010). TSOs in Nordic countries traditionally employed fewer paid workers and were less oriented to social service provision than those of other developed countries. They were also more reliant overall on member and volunteer input than elsewhere in Western Europe (Salamon et al. 1999). A variety of 
societal developments and institutional changes have transformed and restructured the environment of TSOs in Nordic countries since the mid-1990s.

In Finland, for example, there was a shift from the idea of 'the welfare state' to 'the welfare society' in the hegemonic societal discourses of the late 1990s. The conceptual shift emphasized the importance of TSOs, mutual aid, and self-help groups in welfare formation. As a consequence the municipalities, the basic providers of welfare services in Finland, have increasingly started sourcing their services to TSOs. Since the mid-1990s, paid employment in Finnish TSOs has increased by $62 \%$. Simultaneously, the number of TSOs employing paid labor has almost doubled (Fig. 1; Statistics Finland 2012).

Figure I: The development of third sector employment in Finland 1990-201 I (full-time equivalent employees) (Statistics Finland 2012)

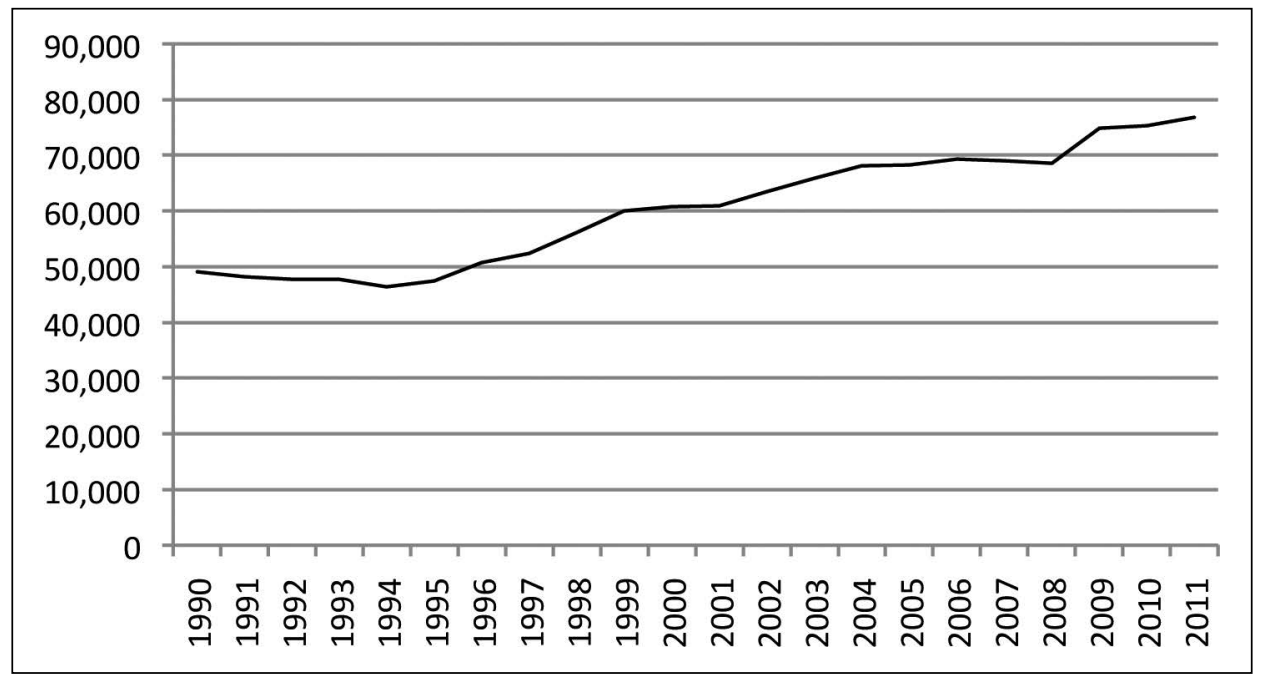

As a part of the so-called welfare mix, TSOs nowadays have an important role as coproducers of public services. This is reflected in the fact that the majority of the employment growth in the third sector has taken place in social and human services. TSOs have been seen as adaptable and flexible partners who can combine paid labor and unpaid voluntary work in their operations and thus produce services more cost-effectively. Contract culture among public organizations has favored public tender procedures for short-term contracts and projects, which has intensified competition between private firms and TSOs (Ascoli and Ranci 2002; Eikås and Selle 2002; Möttönen and Niemelä 2005). Acting as a contractor in the public sector supply chain may lead to squeezing costs and demanding more results with fewer permanent resources, which may lead to intensification of work in the third sector. This probably undermines job quality and job satisfaction in the sector (Cunningham and James 2009; Ruuskanen et al. 2016; Shragge et al. 2001). 


\section{Turnover Intentions and Motivation for Public Service}

Turnover intentions refer to employees' intentions to voluntarily quit their current job. It is an important construct in itself, but also because intentions have been shown to predict actual turnover behavior (e.g., Griffeth et al. 2000). ${ }^{1}$

One possibility for analyzing third sector employees' attraction to their work is public service motivation theory. It suggests that nonprofit institutions attract employees who want to serve the community and help others (Perry and Wise 1990). Originally the concept was associated with public institutions, but as the TSOs have increasingly taken care of public services, discussion has spread beyond the sector boundaries. In the empirical studies especially, third sector employees have been observed to share similar concerns with services that enrich communities and civil society (Park and Word 2012). This makes work more meaningful (Perry and Wise 1990) and thus it has been used to explain, for example, high job satisfaction (Naff and Crum 1999), high job and organizational performance (Alonso and Lewis 2001; Brewer and Coleman Selden 2000), and low turnover intentions (Bright 2008; Crewson 1997).

Public service motivation, however, is not solely related to an individual's attitude. It evolves in the interaction with the institutional context, which provides limits in which employees are able to express their desire to do good for others (Perry and Vandenabeele 2008). For example, because third sector and public institutions have different goals, there is some variation in public service motivation. Previous studies have suggested that third sector employees are not that interested in public policy making, but rather their service motivation is more related to the local level (Lee and Wilkins 2011; Word and Carpenter 2013).

On the other hand, previous studies have also observed that, although public service motivation can attract employees to third and public sectors, benefits are short lived if the operating environment does not support employees' motivation for public service (Bright 2008; Moynihan and Pandey 2007; Wright and Pandey 2008). Moynihan and Pandey (2008) and Bright (2008) have suggested that the working environment has to be compatible with employees' values in order for public service motivation to increase job satisfaction or decrease turnover. This article therefore considers value congruence between the employee and the organization alongside public service motivation. The previous discussion leads to the following hypotheses:

H1a: Public service motivation decreases third sector employees' turnover intentions.

H1b: Value congruence decreases third sector employees' turnover intentions.

\section{Job Quality and Turnover Intentions in the Third Sector}

Recent studies suggest that identification with an organization's mission and values is an important reason to stay in the TSO, but it is not enough to retain employees if they are dissatisfied with their working conditions (see Brown and Yoshioka 2003; Kim and Lee 2007). Kim and Lee (2007), for example, observed that dissatisfaction with working conditions, such as pay and advancement opportunities, was able to override the importance of public service motivation and mission attachment. 
Based on previous studies we know that job quality is associated with turnover intentions (e.g., Alexander et al. 1998; Mor Barak et al. 2001). In this article, the term 'job quality' will be used to refer to working conditions. It includes pay satisfaction, advancement opportunities, job security, work climate, intensity of work, job autonomy, and skills discretion. These are important dimensions of job quality (Eurofound 2012; Green 2006) and predictors of turnover intentions (Alexander et al. 1998; Mor Barak et al. 2001; Sverke et al. 2002).

Pay satisfaction, advancement opportunities, and job security can be considered as extrinsic aspects of job quality. They satisfy employees' material and psychosocial needs and thus explain why employees need the workplace (Eurofound 2012). Previously, all of these have been associated with decreased turnover intentions (Sverke et al. 2002; Williams et al. 2006).

In third sector studies, low pay satisfaction and lack of advancement opportunities have been considered as the main reasons for turnover intentions (Ban et al. 2003; Brown and Yoshioka 2003; Kim and Lee 2007). These studies, however, did not take account of job security. Since many employees expect job security from their work (Rousseau 1990), unmet expectations of job security can be one reason to change workplace. Thus three hypotheses follow from this discussion:

H2a: Pay satisfaction decreases third sector employees' turnover intentions.

$H 2 b$ : Advancement opportunities decrease third sector employees' turnover intentions.

$H 2 c$ : Job security decreases third sector employees' turnover intentions.

Work climate, job autonomy, opportunities to use skills, and intensity of work can be considered as intrinsic aspects of job quality. They are important in meeting employees' needs and generating well-being (Eurofound 2012). In this study, work climate is used as a general concept to refer to an inspiring and supportive workplace environment. Helpful social interaction with coworkers and supervisors helps employees to get new information and thus perform better in their job. Social interaction also satisfies employees' need to belong to social groups and be accepted (Cohen and Syme 1985). Job autonomy, which is discretion over work, and opportunities to use skills, in turn, help employees to do their work. These help employees to control their workload if the work pace is intense. Otherwise, intensity of work can be stressful for employees and thus increase turnover intentions (Alexander et al. 1998; Karasek 1979). According to empirical studies, good work climate such as social support and work group friendliness, job autonomy, and opportunities to use skills decrease turnover intentions (Alexander et al. 1998; Hwang and Chang 2009; Kim and Stoner 2008; Mor Barak et al. 2001).

In the literature, TSOs have been assumed to use managerial practices that are designed to strengthen employees' ideological orientation to work (see, e.g., Mirvis and Hackett 1983). For example, work has been found to offer employees more variety, better opportunities to express themselves freely in the job, and better job autonomy than private or public sector organizations (Becchetti et al. 2014; Borzaga and Tortia 2006; McMullen and Schellenberg 2003; Mirvis and Hackett 1983; Ruuskanen et al. 2016). A downside, however, seems to be that TSOs give less direct feedback on how employees are performing in their work than public or private sector organizations (Mirvis and Hackett 1983). Thus informal working practices and flexibility can also result in problems in the work climate since the work is not clearly structured. Also, the intensity of 
work has been observed as a major problem in the third sector working environment (McMullen and Schellenberg 2003; Ruuskanen et al. 2016). Thus, four hypotheses follow from this discussion:

H2d: Good work climate reduces third sector employees' turnover intentions.

H2e: Job autonomy decreases third sector employees' turnover intentions.

H2f: Opportunities to use skills decrease third sector employees' turnover intentions.

$H 2 g$ : Intensity of work increases third sector employees' turnover intentions.

\section{Data and Methods}

Statistics Finland has a tradition of over thirty years of collecting information on job quality and turnover intentions. The latest Quality of Work Life (QWL) survey was conducted in 2013 with face-to-face interviews. At that time, the response rate was $69 \%$ and the net sample 4,876 employees. QWL, however, is not designed for sector comparisons. It provides a good overview of public and private sector employees. It does not, however, provide a representative picture of third sector employment. Therefore, another form of data for third sector employees had to be gathered. In order to increase the reliability of the measurements and maintain comparability with other sectors, we used the same standardized questions and response options as in the QWL study.

The problem with collecting data from the third sector is that in Finland there is no national register of third sector employees. Trade unions, instead, register the information if their member's employer organization is an association or foundation. Since in Finland trade union density is still exceptionally high (70-80\%) (Donegani and McKay 2012; OECD 2012), membership registers represent third sector employees quite well and so were used in data collection. Expert interviews revealed four central trade unions: Akava Special Branches (Akavan erityisalat), The Trade Union for the Public and Welfare Sectors (JHL), the Federation of Special Service and Clerical Employees (ERTO), and the Union of Professional Social Workers (Talentia). Members of these trade unions whose employer was an association or foundation were further invited to take part in the third sector survey.

The third sector survey was conducted in 2011 using the Internet and a postal survey. All of those who had provided their e-mail address were sent an e-mail with a web link to the questionnaire. However, in ERTO and JHL, more than a quarter of the people did not have e-mail addresses, and so the Internet survey was supplemented with a postal survey in these two unions. The participants for the postal survey were selected by systematic random sampling from those whose e-mail address was not available. Altogether, the response rate for the whole third sector data was $22 \%$ and the net sample 1,412. The main reason for the low response rate can be attributed to the Internet survey. In the Internet survey, response activity was $21 \%$, whereas in the postal survey it was $41 \%$. Possible reasons for the low response activity in the Internet survey include increased unsolicited 'junk' mail and obsolete e-mail addresses. Thus only $30 \%$ of e-mail recipients opened the survey. Because of the low response rate data may suffer self-selection bias. The usual approach to overcome this problem would be missing data analysis. In the third sector case, however, it is difficult since comparative data are absent in Finland. To our knowledge, the only possibility is to compare data to Statistics 
Finland's (StatFi) business register (2012) of third sector activities. Comparison showed that the data represent third sector activities quite well. Only education and research are underrepresented in the third sector data (social and health care: StatFi 44\%, third sector data $47 \%$; education and research: StatFi $16 \%$, third sector data $6 \%$; activities of membership organizations: StatFi $15 \%$, third sector data $16 \%$; culture, sport and recreation: StatFi $11 \%$, third sector data $14 \%$; business and professional associations and unions: StatFi $8 \%$, third sector data $7 \%$ ).

In the sector comparisons, QWL and third sector data were combined. Since previous studies have found that union membership decreases turnover intentions (e.g., Sousa-Poza and Henneberger 2004), only those QWL respondents who are members of trade unions $(\mathrm{N}=3,445)$ were selected. Thus, the combined data comprise 4,857 respondents: $29 \%$ of these belong to the third sector, $32 \%$ to the public sector, and $40 \%$ to the private sector.

\section{Measures}

\section{Dependent variable}

Turnover intentions were measured with the same question as in the QWL survey. Respondents were asked whether they would change their job at the same pay to 'the same occupational field', 'a different occupational field', or 'wouldn't change at all.' For the analysis, two first response options were combined into one: 'would change the workplace.' This was done because this article concentrates on the issue regarding 'why third sector employees have turnover intentions' instead of answering 'where' they want to leave.

\section{Independent variables}

Independent variables include public service motivation, value congruence, and job quality. In previous studies, public service motivation is most often measured with James Perry's scale (1996). Because of data limitations, however, this study was not able to use the original scale. Instead, public service motivation was measured by three questions which mostly resemble Perry's subscale-commitment to public interest-and thus it gives insight into the relationship between turnover intentions and third sector employees' desire to serve the community. The questions include: to what extent do you consider that your work 'is socially useful', 'gives sense of accomplishing something worthwhile', and 'it enables me to help and take care of other people' ( $1=$ not important to $5=$ very important $)$. Together these form a mean sum variable $(M=4.24, S D=0.68$, Cronbach $\alpha=0.70)$. Value congruence, in turn, was measured by one question: 'I find that my values and the organization's values are very similar' $(1=$ totally disagree to 5 = totally agree; $M=3.83, S D=0.99$ ).

This study applies a multidimensional approach to job quality. Following Green (2006) and the Eurofound (2012) report, this study measures job quality with seven variables. These include pay satisfaction, advancement opportunities, job security, work climate, job autonomy, opportunities to use skills, and work intensity. Pay satisfaction 
was asked through the following question: 'how satisfied you are with the pay received from the work' ( 1 = very dissatisfied to $5=$ very satisfied; $M=2.97, S D=1.24)$. Advancement opportunities were also measured by one question: 'in your current workplace, are your advancement opportunities 1 = poor, 2 = fair, or 3 = good' $(M=1.44, S D=0.61)$ ? The third variable, job security, in turn, consisted of three threats: 'temporary dismissal', 'dismissal', and 'unemployment' (response options $0=$ yes and $1=$ no). Together these form the job security index, which can have values from 0 to $3(M=2.46, S D=0.94$; Cronbach $\alpha=0.75)$. Work climate consists of four statements related to employees' own workplace. Employees were asked whether the atmosphere is 'open and team spirit prevails', is it 'inspiring', 'are work arrangements or problems discussed sufficiently', and is the 'communication open' (response options from $1=$ totally disagree to $5=$ totally agree)? Together these form a mean sum variable $(M=3.29, S D=1.05$, Cronbach $\alpha=0.90)$. Job autonomy was measured with three questions. Respondents were asked whether they are able to influence '... the content of their tasks' ' '... working methods', and '.. working hours' (response options from $1=$ never to $4=$ always). The mean of these scores forms a sum variable $(M=2.72, S D=0.63$, Cronbach $\alpha=0.75)$. The skills, in turn, involve one question: 'are you able to apply your own ideas at work' (response options from 1 = never to 4 = always; $M=2.93, S D=0.72$ ) ? The last variable, work intensity, was measured with three questions. These were: 'how much does your work contain tight time schedules?' 'how often do you need to stretch your working day in order to get all the work done?' and 'how often do you feel that you do not have enough time to do work as well and conscientiously as you would like to?' (response options from $1=$ never to $4=$ always $)$. The mean of these item scores forms a sum scale $(M=2.50$, $S D=0.72$, Cronbach $\alpha=0.66$ ).

Some of these independent variables involve only one question. Thus, in a strict statistical sense, they are not continuous. Nevertheless, because treating them as ordinal in the analysis did not have an effect on the results, they were interpreted as continuous. This reduced the number of parameters which needed to be estimated and made interpretation more straightforward.

\section{Background variables}

In addition to the independent variables, this article uses several background variables to enhance the generalizability of the findings. In the third sector there are more females than in the public or private sector. They are also a bit older and more often have higher education than employees in the private sector. Furthermore, there are more employees working in the social and health care and higher occupational positions than elsewhere. The workplaces, instead, are smaller and employees have permanent work contracts less often than employees in the public or private sector (see Tab. I).

\section{Methods}

Analysis is mainly based on logistic regression. It is a multiple regression method that can be used to evaluate simultaneous contributions of multiple predictors of turnover intentions. In the first section, we asked whether third sector employees report more 
Table I Structural differences between third, public, and private sector

\begin{tabular}{llccc}
\hline & & \multicolumn{3}{c}{ Sector } \\
\cline { 3 - 5 } & & Third & Public & Private \\
\hline Gender & Female (\%) & 85 & 72 & 43 \\
& Male (\%) & 15 & 28 & 57 \\
\hline Age & Years, mean (SD) & $45(11)$ & $47(11)$ & $43(12)$ \\
\hline Education & Primary (\%) & 5 & 6 & 12 \\
& Secondary (\%) & 40 & 35 & 47 \\
& Higher (\%) & 55 & 60 & 41 \\
\hline Activity of employer organization & Social and health care (\%) & 45 & 40 & 7 \\
& Other (\%) & 55 & 60 & 93 \\
\hline Occupational class & Worker (\%) & 24 & 37 & 59 \\
& Expert (\%) & 61 & 61 & 39 \\
& Manager (\%) & 14 & 3 & 3 \\
\hline Size of workplace & $<10$ employees (\%) & 40 & 21 & 24 \\
& I0-49 employees (\%) & 38 & 46 & 35 \\
& $>50$ employees (\%) & 19 & 33 & 41 \\
\hline Employment contract & Permanent (\%) & 79 & 83 & 94 \\
& Fixed (\%) & 21 & 17 & 6 \\
\hline $\mathrm{N}$ & & 1,412 & 1,528 & 1,917 \\
\hline
\end{tabular}

According to chi-squared test used in cross-tabulations and variance analysis all differences are statistically significant $(p<0.00 \mathrm{I})$.

turnover intentions than employees in the private or public sector. Logistic regression was used to control structural differences between sectors. In the second section, we focused more on third sector employees. We wanted to reveal what increased or decreased their turnover intentions. In this part, the logistic regression analysis was conducted stepwise with an enter method. The first step includes variables that are related to employees. Public service motivation was added in the second step and value congruence in the third step. In the last step, we added variables that are related to job quality. With this hierarchical structure, it was possible to show how connection between public service motivation and turnover intention changes after other variables are included in the model.

\section{Turnover Intentions in the Third, Public, and Private sector}

The findings reveal that Finnish third sector employees report more turnover intentions than employees in the public and private sector (see Fig. 2). Only one-third (31\%) of third sector employees say that they would not change their workplace if they were offered another job at the same pay. In the public $(56 \%)$ and private $(48 \%)$ sectors, about half of the employees would refuse to change their workplace despite the same pay. 
Figure 2: Percentage distribution of turnover intentions in third, public, and private sector. According to cross-tabulation, differences between sectors are statistically significant $\left(\chi^{2}=168.85, \mathrm{df}=2, p<0.00 \mathrm{I}\right)$

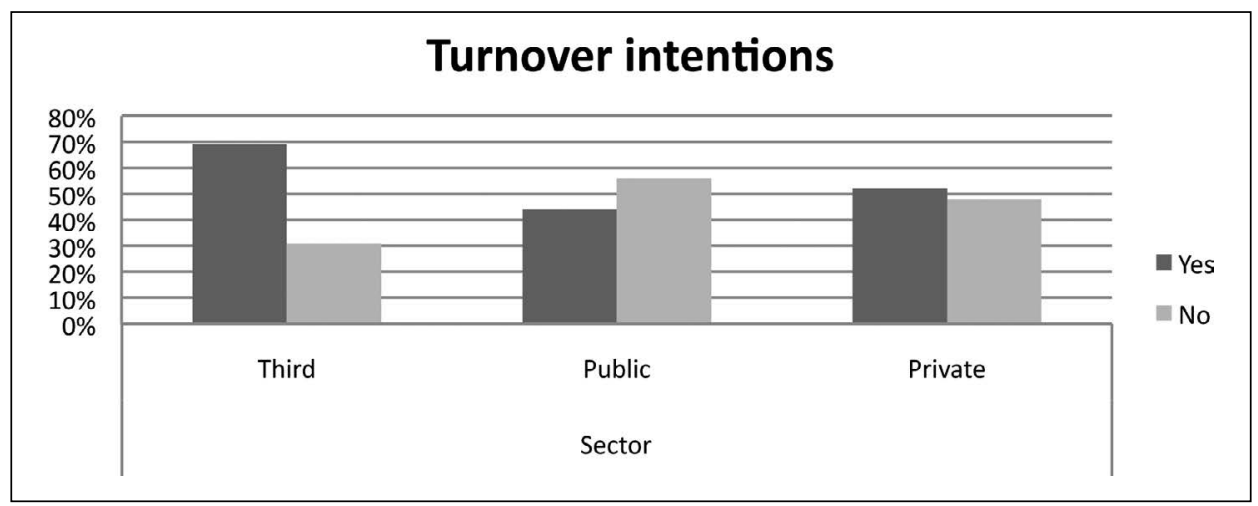

Nevertheless, before drawing conclusions regarding sectoral differences in turnover intentions, it has to be established that they are not related to structural differences between the sectors (see Tab. I). To control gender, age, education, activity of the employer organization, occupational structure, size of the workplace, and type of employment contract, a logistic regression analysis was performed (see Tab. III in the Appendix). This confirms that third sector employees' turnover intentions are higher than their counterparts in the public or private sector, even after controlling for background variables.

\section{Why Are Turnover Intentions High in the Third Sector?}

Analysis of third sector employees' turnover intentions began by examining Spearman's correlation coefficients. This revealed that most of the variables (age, education, occupational class, public service motivation, value congruence, pay satisfaction, advancement opportunities, job security, work climate, job autonomy, skills, and work intensity) are correlated with turnover intentions. Only gender, employment in social and health care, workplace size, and type of employment contract are uncorrelated with turnover intentions (see Tab. IV in the Appendix). This indicates that third sector turnover intentions are not related to third sector workforce female domination, concentration on social and health care occupations, small workplaces, or a bigger share of fixed term contracts. Therefore, these variables were left out of the logistic regression model.

The first step of the logistic regression analysis includes variables that are related to employees. These include age, education, and occupational class (see Tab. II). From Table II it can be seen that age reduces turnover intentions. Young employees are more willing to change their workplace than older employees. This is consistent with previous studies. Those have suggested that young employees have more recent education which makes leaving easier (Griffeth et al. 2000; Mor Barak et al. 2001). Education as a separate variable, however, is not related to turnover intentions. Low or high education does not guarantee that employees would be more likely to stay in their workplace. 


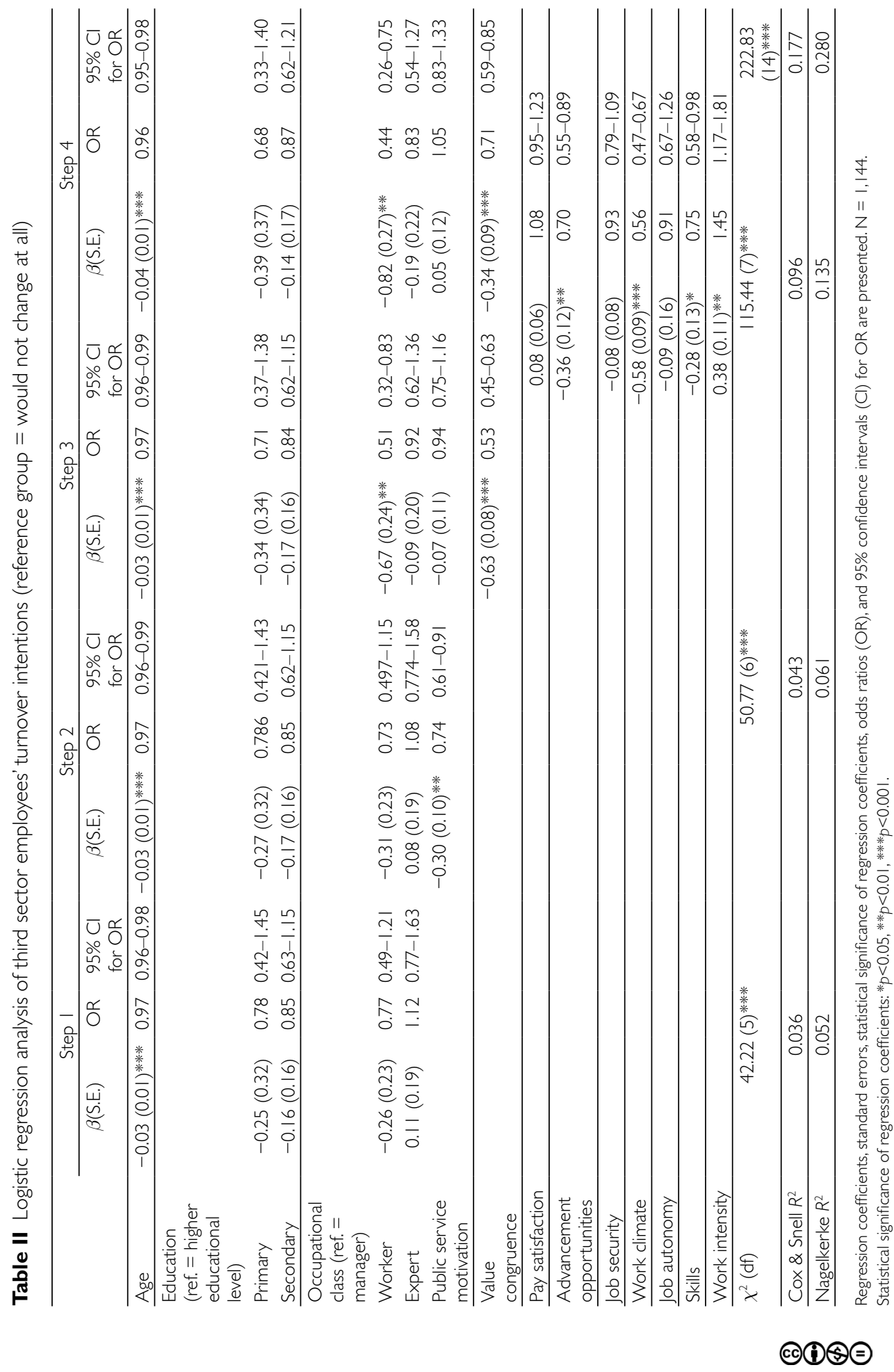


Occupational class, however, seems to explain turnover intentions (see Tab. II). In the first step, occupational class is not connected to turnover intentions but after other variables are included in the model, managers are more willing to change their workplace than workers. This suggests that connection between turnover intentions and occupational class is dependent on other variables. Previously for example, Mor Barak and her colleagues (2001) have suggested that managers' knowledge and skills are more general and thus more easily transferable than workers' expertise. Therefore they may be more likely to leave their workplace (ibid.).

Public service motivation was added to the model in the second step (see Tab. II). This increased the model's explanation and showed that it is an important part of employees' turnover intentions. From Table II, it can be seen that public service motivation decreases employees' turnover intentions. Hypothesis 1a, however, is only partially supported since in the third step, connection between public service motivation and turnover intentions disappears after value congruence is included in the model. This indicates that value congruence acts as a so-called intervening variable. Interest for public service may attract employees to work in these occupations, but it is not enough to keep employees if the organization's values are inconsistent with the employees' values. This supports previous studies which have suggested that individual's motivation for public service is not enough to reduce turnover intentions if the organizational environment does not support such behavior (Bright 2008; Moynihan and Pandey 2007; Wright and Pandey 2008).

As already mentioned, value congruence seems to be an important part of third sector employees' turnover intentions. From the third step of the model (see Tab. II) it can be seen that value congruence decreases turnover intentions. This supports our hypothesis $1 \mathrm{~b}$ and conclusions of previous studies (e.g., Bright 2008; Moynihan and Pandey 2008).

In addition to public service motivation and value congruence, it was assumed that job quality could explain turnover intentions. Although all dimensions were correlated with turnover intentions, only some of them were statistically significant after other variables were controlled in the logistic regression analysis (see Tab. II). Of the extrinsic dimensions of job quality, only advancement opportunities were able to decrease turnover intentions (hypothesis $2 \mathrm{~b}$ ). This is consistent with previous findings which have shown that a lack of career opportunities is one of the reasons why the third sector loses qualified employees (e.g., Kang et al. 2015; Kim and Lee 2007). According to previous studies, another important reason to leave is pay satisfaction (Brown and Yoshioka 2003; Kim and Lee 2007). Therefore, it is surprising that in our data, pay satisfaction was not a statistically significant antecedent of turnover intentions. This is against hypothesis 2a. Previous studies come mainly from Anglo-Saxon countries in which the third sector role in welfare service provision is stronger than in Nordic countries (Salamon et al. 2003). Since competition in welfare service provision requires more cost-effective orientation from organizations, employees may also expect material benefits such as good pay, instead of work that is intrinsically rewarding and valuable for society. Another possible reason for contradicting results can be related to the more equal income distribution and higher income taxes in the Nordic countries, which probably decreases the economic incentives to change the workplace. Lastly, one of the extrinsic dimensions of job quality was job security. Even though it correlated with turnover intentions (see Tab. IV) it is not associated with turnover intentions after other variables are taken into 
account in the logistic regression model (see Tab. II). This is against hypothesis $2 \mathrm{c}$ and previous turnover studies (Sverke et al. 2002). For third sector employees, job security is not as important as other aspects in their work environment.

Of the remaining job quality dimensions, work climate turned out to be the most important for turnover intentions. A good working atmosphere decreases turnover intentions and thus supports hypothesis $2 \mathrm{~d}$ as well as findings of previous turnover studies (e.g., Hwang and Chang 2009). In order to retain employees in the organization, the working atmosphere has to be open and inspiring, and work arrangements and problems should be adequately discussed. Furthermore, the intensity of work and opportunities to use skills were connected to turnover intentions. This supports hypotheses $2 \mathrm{~g}$ and $2 \mathrm{f}$ as well as findings of previous turnover studies (e.g., Alexander et al. 1998). Job autonomy, on the other hand, was not associated with turnover intentions after controlling other variables. This rejects our hypothesis $2 \mathrm{e}$. In some of the previous studies, job autonomy was associated with turnover intention (Mor Barak et al. 2001), while in others it was not (e.g., Kim and Stoner 2008). Thus the association may be related to other variables.

The logistic regression analysis shows that employees who share the values of the employer organization prefer to stay in their workplace. At the same time, however, these employees may have turnover intentions because of low job quality. In particular, problems regarding work climate, intensity of work, lack of advancement opportunities, and lack of opportunities to use skills are associated with turnover intentions. These problems might explain the sectoral differences observed in Figure 2. TSOs should therefore pay more attention to job quality.

\section{Discussion}

Previously, it has been suggested that TSOs attract employees who want to be involved in serving the public interest and civil society, even if it requires self-sacrifice (Park and Word 2012; Perry and Wise 1990). Thus, motivation for public service could keep employees in their workplace. On the other hand, it is not enough to retain employees if they are dissatisfied with their working conditions (see Brown and Yoshioka 2003; Kim and Lee 2007).

In the Nordic countries, TSOs have increasingly turned from interest organizations to welfare service providers (Alapuro and Stenius 2010; Wijkström 2011). This study, conducted in Finland, studied third sector's employees' turnover intentions for the first time in the Nordic context. The study tested the public service motivation for keeping employees in their workplaces and the job quality associated with turnover intentions. The analysis shows that certain dimensions of job quality explain third sector employees' turnover intentions. Work climate, work intensity, advancement opportunities, and skills proved to be important antecedents of turnover intentions. These are also variables in which previous studies detected problems in the third sector (McMullen and Schellenberg 2003; Mirvis and Hackett 1983; Ruuskanen et al. 2016). This partly explains why third sector employees in Finland report higher turnover intentions than employees in the public or private sector.

Public service motivation, on the other hand, is connected to turnover intentions but its ability to reduce turnover intentions is dependent on the organizational context. More important than employees' desire to help others is their sharing of the employer 
organization's values and that the organization provides high job quality. This is consistent with previous studies which have shown that public service motivation is not enough to retain employees in their workplace, if the organization is not congruent with employees' needs and values (Bright 2008; Wright and Pandey 2008).

Even though public service motivation cannot keep employees in the TSO, congruent values with the employer organization seem to inhibit turnover intentions. This is against previous studies from Anglo-Saxon countries in which employees' identification with the organization's mission and values was not considered as an important reason to stay in the TSOs (Brown and Yoshioka 2003; Kim and Lee 2007). As noted above, in Anglo-Saxon countries the role of the TSOs in welfare service provision has traditionally been strong, whereas in Nordic countries they have been more focused on providing advocacy and interest representation. This difference may still be reflected in employees' attitudes.

Differences between studies, however, can be related to differences in measurements, but it is also tempting to conclude that third sector employees in Finland have a more intrinsically motivated attitude toward their work. For Finnish third sector employees, pay satisfaction is not as important as for employees in the Anglo-Saxon countries, and values are more important in keeping employees. This kind of conclusion, however, requires that future studies use the same measurements and include more countries in the data collection.

A more practical implication of the research is that TSO management principles are not very effective in reducing turnover intentions in Finnish TSOs. It has been recommended that TSOs select employees with strong public service motivation (e.g., RoseAckerman 1996), but, according to this study, it does not reduce turnover intentions if employees' orientation to public service is not nurtured by the employer organization. TSOs should recruit and retain mission-driven employees who share the employer organization's values. Employees should also be guaranteed high job quality. This has become even more important in recent years because the competition for welfare service provision in Nordic countries gets tougher and TSOs probably adapt more and more practices from the private sector. Thus it is possible that employees feel that the organization is more interested in efficiency rather than its original goals and values. Managers should therefore signal to employees that seeking for efficiency is based on the organization's values. Furthermore, TSOs should also change their management principles. Previously, TSOs were seen to offer lots of autonomy and variety for their employees, but because organizations are not formally arranged, there are problems with the work climate and work pace (e.g., Borzaga and Tortia 2006; Mirvis and Hackett 1983). For turnover intentions, however, it would be more important to provide an inspiring and supportive work climate and decent work pace than lots of autonomy. Third sector managerial practices should thus be changed in a way that they improve the work climate and reduce the intensity of the work.

These suggestions, however, should be interpreted with caution. First, in a strict statistical sense, conclusions of causality cannot be made because analysis is based on a cross-sectional data set. Secondly, generalizability can be questioned. This is because of the low response rate and possible self-selection bias. Also, data collection using trade union membership may limit our findings to trade union members instead of the whole third sector. Thirdly, there is also some limitation related to our dependent variable. Our analysis relies only on one dependent variable which is a not neutral intention to

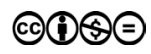


leave the job. We asked whether employees would change their job at the same pay. Thus employees' turnover intentions in this case reveal their satisfaction with their work content instead of wage. If we had asked about general turnover intentions, it would be possible that the difference with other sectors would have been even bigger because employees in the third sector may be looking for a better wage level.

Nevertheless, despite these deficiencies, this article is the first one that has provided information about third sector employees' turnover intentions in the Nordic context. It was able to show that Finnish third sector employees have more turnover intentions compared with their counterparts in the public and private sectors, because of the low quality of the work. At the same time, however, these employees would like to stay in their workplace because of congruent values with the employer organizations. Since values keep employees in the TSOs, future studies could analyze how long and how much these employees are willing to stand for low job quality before they start considering leaving the organization. Also, the question of whether they want to stay in the same sector requires more focus in the future.

\section{Note}

${ }^{1}$ In this article we will concentrate on the factors that make work appealing for the employee. Thus, it does not take account of the availability of alternatives such as open job positions that are part of the turnover behavior process (Hulin et al. 1985; Mobley 1977).

\section{References}

Alapuro, R. and H. Stenius (eds.) (2010) Nordic Associations in a European Perspective Baden-Baden: Nomos. doi: http://dx.doi.org/10.5771/9783845225944.

Alexander, J., R. Lichtenstein, H. Oh and E. Ullman (1998) A causal model of voluntary turnover among nursing personnel in long-term psychiatric settings, Research in Nursing \& Health 21(5): 415-424. doi: http://dx.doi.org/10.1002/(SICI)1098240X(199810)21:5;415::AID-NUR5;3.0.CO;2-Q.

Alonso, P. and G. Lewis (2001) Public service motivation and job performance: Evidence from the federal sector, The American Review of Public Administration 31(4): 363-380. doi: http://dx.doi.org/10.1177/02750740122064992.

Ascoli, U. and C. Ranci (2002) The context of new social policies in Europe, in Ascoli, U. and C. Ranci (eds.) Dilemmas of the Welfare Mix. The New Structure of Welfare in an Era of Privatization. New York: Kluwer Academic/Plenum Publishers, 1-24. doi: http://dx.doi. org/10.1007/978-1-4757-4992-2.

Ban, C., A. Drahnak-Faller and M. Tower (2003) Human resource challenges in human service and community development organizations: recruitment and retention of professional staff, Review of Public Personnel Administration 23(2): 133-153. doi: http://dx.doi.org/10.1177/0734371X03023002004.

Becchetti, L., S. Castriota and S. Depedri (2014) Working in the for-profit versus not-for-profit sector: What difference does it make? An inquiry on preferences of voluntary and involuntary movers, Industrial and Corporate Change 23(4): 1087-1120. doi: http://dx.doi. org/10.1093/icc/dtt044.

Benz, M. (2005) Not for the profit, but for the satisfaction? Evidence on worker well-being in non-profit firms, Kyklos 58(2): 155-176. doi: http://dx.doi.org/10.1111/j.00235962.2005.00283.x. 
Borzaga, C. and E. Tortia (2006) Worker motivations, job satisfaction, and loyalty in public and nonprofit social services, Nonprofit and Voluntary Sector Quarterly 35(2): 225-248. doi: http://dx.doi.org/10.1177/0899764006287207.

Brewer, G. and S. Coleman Selden (2000) Why elephants gallop: Assessing and predicting organizational performance in federal agencies, Journal of Public Administration Research and Theory 10(4): 685-711. doi: http://dx.doi.org/10.1093/oxfordjournals.jpart. a024287.

Bright, L. (2008) Does public service motivation really make a difference on the job satisfaction and turnover intentions of public employees? The American Review of Public Administration 38(2): 149-166. doi: http://dx.doi.org/10.1177/0275074008317248.

Brown, W. and C. Yoshioka (2003) Mission attachment and satisfaction as factors in employee retention, Nonprofit Management \& Leadership 14(1): 5-18. doi: http://dx.doi. org $/ 10.1002 / \mathrm{nml} .18$.

Cohen, S. and L. Syme (1985) Issues in the study and application of social support, in Cohen, S. and L. Syme (eds.) Social Support and Health. London: Academic Press, 3-22.

Crewson, P. (1997) Public-service motivation: Building empirical evidence of incidence and effect, Journal of Public Administration Research and Theory 7(4): 499-518. doi: http://dx.doi.org/10.1093/oxfordjournals.jpart.a024363.

Cunningham, I. and P. James (2009) The outsourcing of social care in Britain: What does it mean for voluntary sector workers? Work, Employment and Society 23(2): 363-375. doi: http://dx.doi.org/10.1177/0950017009102863.

Donegani, C.P. and S. McKay (2012) Is there a paradox of lower job satisfaction among trade union members? European evidence, Transfer 18(4): 471-489. doi: http://dx.doi. org/10.1177/1024258912459312.

Eikås, M. and P. Selle (2002) A contract culture even in Scandinavia, in Ascoli, U. and C. Ranci (eds.) Dilemmas of the Welfare Mix. The New Structure of Welfare in an Era of Privatization. New York: Kluwer Academic/Plenum Publishers, 47-75. doi: http://dx.doi. org/10.1007/978-1-4757-4992-2 3.

Eurofound (2012) Trends in Job Quality in Europe: A Report Based on the $5^{\text {th }}$ European Working Condition Survey. Luxembourg: Publications Office of the European Union. doi: http://dx.doi.org/10.2806/35164.

Green, F. (2006) Demanding Work: The Paradox of Job Quality in the Affluent Economy. Princeton: Princeton University Press.

Griffeth, R., P. Hom and S. Gaertner (2000) A meta-analysis of antecedents and correlates of employee turnover: update, moderator tests, and research implications for the next millennium, Journal of Management 26(3): 463-488. doi: http://dx.doi.org/10.1016/S01492063(00)00043-X.

Hansmann, H. (1980) The role of nonprofit enterprise, The Yale Law Journal 89(5): 835-901. doi: http://dx.doi.org/10.2307/796089.

Hulin, C., M. Roznowski and D. Hachiya (1985) Alternative opportunities and withdrawal decisions: Empirical and theoretical discrepancies and an integration, Psychological Bulletin 97(2): 233-250. doi: http://dx.doi.org/10.1037/0033-2909.97.2.233.

Hwang, J.I. and H. Chang (2009) Work climate perception and turnover intention among Korean hospital staff, International Nursing Review 56(1): 73-80. doi: http://dx.doi. org/10.1111/j.1466-7657.2008.00641.x.

Kang, C., S. Huh, S. Cho and E.Y. Auh (2015) Turnover and retention in nonprofit employment: The Korean college graduates' experience, Nonprofit and Voluntary Sector Quarterly 44(4): 641-664. doi: http://dx.doi.org/10.1177/0899764014553032.

Karasek, R. (1979) Job demands, job decision latitude, and mental strain: Implications for job redesign, Administrative Science Quarterly 24(2): 285-308. doi: http://dx.doi. org/10.2307/2392498. 
Kendall, J. (ed.) (2009) Handbook on Third Sector Policy in Europe. Multi-Level Processes and Organized Civil Society Cheltenham: Edward Elgar. doi: http://dx.doi. org/10.4337/9781849803403.

Kim, S. and J. Lee (2007) Is mission attachment an effective management tool for employee retention? An empirical analysis of a nonprofit human services agency, Review of Public Personnel Administration 27(3): 227-248. doi: http://dx.doi.org/10.1177/0734371X06295791.

Kim, H. and M. Stoner (2008) Burnout and turnover intention among social workers: Effect of role stress, job autonomy and social support, Administration in Social work 32(3): 5-25. doi: http://dx.doi.org/10.1080/03643100801922357.

Lee, Y.J. and V. Wilkins (2011) More similarities or more differences? Comparing public and nonprofit managers' job motivations, Public Administration Review 71(1): 45-56. doi: http://dx.doi.org/10.1111/j.1540-6210.2010.02305.x.

McMullen, K. and G. Schellenberg (2003) Job quality in non-profit organizations, CPRN Research Series on Human Resources in the Non-profit Sector 2. Ottawa: Canadian Policy Research Networks.

Mirvis, P. and E. Hackett (1983) Work and workforce characteristics in the nonprofit sector, Monthly Labor Review 116(4): 3-12.

Mobley, W. (1977) Intermediate linkages in the relationship between job satisfaction and employee turnover, Journal of Applied Psychology 62(2): 237-240. doi: http://dx.doi. org/10.1037/0021-9010.62.2.237.

Mor Barak, M., J. Nissly and A. Levin (2001) Antecedents to retention and turnover among child welfare, social work, and other human service employees: What can we learn from past research? A review and metaanalysis, Social Service Review 75(4): 652-661. doi: http://dx.doi.org/10.1086/323166.

Moynihan, D. and S. Pandey (2007) The role of organizations in fostering public service motivation, Public Administration Review 67(1): 40-53. doi: http://dx.doi.org/10.1111/ j.1540-6210.2006.00695.x.

Moynihan, D. and S. Pandey (2008) The ties that bind: Social networks, person-organization value fit, and turnover intention, Journal of Public Administration Research and Theory 18(2): 205-227. doi: http://dx.doi.org/10.1093/jopart/mum013.

Möttönen, S. and J. Niemelä (2005) Kunta ja kolmas sektori: Yhteistyön undet muodot. [Municipality and Third Sector: New Forms of Cooperation] Jyväskylä: PS-kustannus.

Naff, K. and J. Crum (1999) Working for America: Does public service motivation make a difference? Review of Public Personnel Administration 19(4): 5-16. doi: http://dx.doi. org/10.1177/0734371X9901900402.

OECD (2012) Trade union density drawn from employment database. [online] Available from: URL:http://stats.oecd.org/Index.aspx?DatasetCode=UN_DEN. [Accessed September 6, 2012].

Park, S. and J. Word (2012) Driven to service: Intrinsic and extrinsic motivation for public and nonprofit managers, Public Personnel Management 41(4): 705-734. doi: http://dx. doi.org/10.1177/009102601204100407.

Perry, J. (1996) Measuring public service motivation: an assessment of construct reliability and validity, Journal of Public Administration Research and Theory 6(1): 5-22. doi: http://dx.doi.org/10.1093/oxfordjournals.jpart.a024303.

Perry, J. and W. Vandenabeele (2008) Behavioral dynamics: Institutions, identities, and self-regulation, in Perry, J. and A. Hondeghem (eds.) Motivation in Public Management: The Call of Public Service. Oxford: Oxford University Press, 56-79.

Perry, J. and L. Wise (1990) The motivational bases of public service, Public Administration Review 50(3): 367-373. doi: http://dx.doi.org/10.2307/976618.

Rose-Ackerman, S. (1996) Altruism, nonprofits, and economic theory, Journal of Economic Literature 34(2): 701-728. 
Rousseau, D. (1990) New hire perceptions of their own and their employer's obligations: A study of psychological contracts, Journal of Organizational Behavior 11(5): 389-400. doi: http://dx.doi.org/10.1002/job.4030110506.

Ruuskanen, P., K. Selander and T. Anttila (2016) Third-sector job quality: Evidence from Finland, Employee Relations. Forthcoming.

Salamon, L.M. and H.K. Anheier (1998) Social origins of civil society: Explaining non-profit sector cross-nationally, Voluntas 9(3): 229-248. doi: http://dx.doi. org/10.1023/A:1022058200985.

Salamon, L.M., H.K. Anheier, R. List, S. Toepler and S.W. Sokolowski (1999) Global Civil Society. Dimensions of the Nonprofit Sector. The Johns Hopkins Comparative Nonprofit Sector Project. Baltimore, MD: The Johns Hopkins Center for Civil Society Studies.

Salamon, L., W. Sokolowski and R. List (2003) Global Civil Society: An Overview. Baltimore, MD: Johns Hopkins University.

Shragge, E., P. Graefe and J.-M. Fontan (2001) The Citizenship Building Consequences of Quebec's Social Economy. Research Report, Family Network. Ottawa: Canadian Policy Research Networks.

Sivesind, K.H. and P. Selle (2010) Civil society in the Nordic countries: Between displacement and vitality, in Alapuro, R. and H. Stenius (eds.) Nordic Associations in a European Perspective. Baden-Baden: Nomos, 89-120. doi: http://dx.doi.org/10.5771/9783845225944.

Sousa-Poza, A. and F. Henneberger (2004) Analyzing job mobility with job turnover intentions: An international comparative study, Journal of Economic Issues 38(1): 113-137. doi: http://dx.doi.org/10.1080/00213624.2004.11506667.

Statistics Finland (2012) Special compilation of business register.

Sverke, M., J. Hellgren and K. Näswall (2002) No security: A meta-analysis and review of job insecurity and its consequences, Journal of Occupational Health Psychology 7(3): 242-264. doi: http://dx.doi.org/10.1037/1076-8998.7.3.242.

Wijkström, F. (2011) 'Charity speak and business talk': The on-going (re)hybridization of civil society, in Wijkström, F. and A. Zimmer (eds.) Nordic Civil Society at a Cross-roads. Transforming the Popular Movement Tradition. Baden-Baden: Nomos, European Civil Society 12: 27-54. doi: http://dx.doi.org/10.1007/s11266-013-9364-7.

Williams, M., M. McDaniel and N. Nguyen (2006) A meta-analysis of the antecedents and consequences of pay level satisfaction, Journal of Applied Psychology 91(2): 392-413. doi: http://dx.doi.org/10.1016/j.sbspro.2014.03.262.

Word, J. and H. Carpenter (2013) The new public service? Applying the public service motivation model to nonprofit employees, Public Personnel Management 42(3): 315-336. doi: http://dx.doi.org/10.1177/0091026013495773.

Wright, B. and S. Pandey (2008) Public service motivation and the assumption of person-organization fit: Testing the mediating effect of value congruence. Administration \& Society 40(5): 502-521. doi: http://dx.doi.org/10.1177/0095399708320187. 


\section{Appendix}

Table III Logistic regression analysis of sectoral differences in turnover intentions (reference group = would not change at all) after controlling background variables

\begin{tabular}{|c|c|c|c|}
\hline & $\beta(S . E)$ & OR & $95 \% \mathrm{Cl}$ for $\mathrm{OR}$ \\
\hline \multicolumn{4}{|l|}{ Sector (ref. $=$ third sector $)$} \\
\hline Public & $-1.05(0.09)^{* * * * *}$ & 0.35 & $0.30-0.41$ \\
\hline Private & $-0.84(0.09)^{* * * *}$ & 0.43 & $0.36-0.52$ \\
\hline \multicolumn{4}{|l|}{ Gender (ref. $=$ female $)$} \\
\hline Male & $-0.02(0.06)$ & 0.98 & $0.87-1.11$ \\
\hline Age & $-0.02(0.00)^{* * * *}$ & 0.98 & $0.97-0.99$ \\
\hline \multicolumn{4}{|c|}{ Education $($ ref. $=$ higher educational level) } \\
\hline Primary & $-0.28(0.11)^{*}$ & 0.76 & $0.62-0.94$ \\
\hline Secondary & $-0.18(0.07)^{* * *}$ & 0.83 & $0.73-0.96$ \\
\hline \multicolumn{4}{|c|}{ Employed in the social and health care } \\
\hline Other field of industy & $0.06(0.07)$ & 1.06 & $0.92-1.23$ \\
\hline \multicolumn{4}{|c|}{ Occupational class (ref. $=$ manager) } \\
\hline Worker & $0.01(0.15)$ & 1.01 & $0.76-1.35$ \\
\hline Expert & $0.01(0.14)$ & 1.01 & $0.78-1.32$ \\
\hline \multicolumn{4}{|c|}{ Size of workplace (ref. $=$ over 50 employees) } \\
\hline$<10$ employees & $-0.09(0.07)$ & 0.91 & $0.79-1.05$ \\
\hline 10-49 employees & $-0.10(0.07)$ & 0.91 & $0.80-1.03$ \\
\hline \multicolumn{4}{|c|}{ Employment contract $($ ref. $=$ fixed) } \\
\hline Permanent & $0.11(0.09)$ & 1.01 & $0.86-1.20$ \\
\hline
\end{tabular}

Regression coefficients, standard deviation, statistical significance of regression coefficients, and odds ratios (OR) are presented. $N=5,727$. Model is statistically significant $\left(\chi^{2}=276.83, \mathrm{df}=12, p<0.001\right.$. Pseudo $R^{2}:$ Cox \& Snell $=0.047$, Nagelkerke $=0.063$.

Statistical significance of regression coefficients: ${ }^{*} p<0.05, * * p<0.01, * * * *<0.001$. 


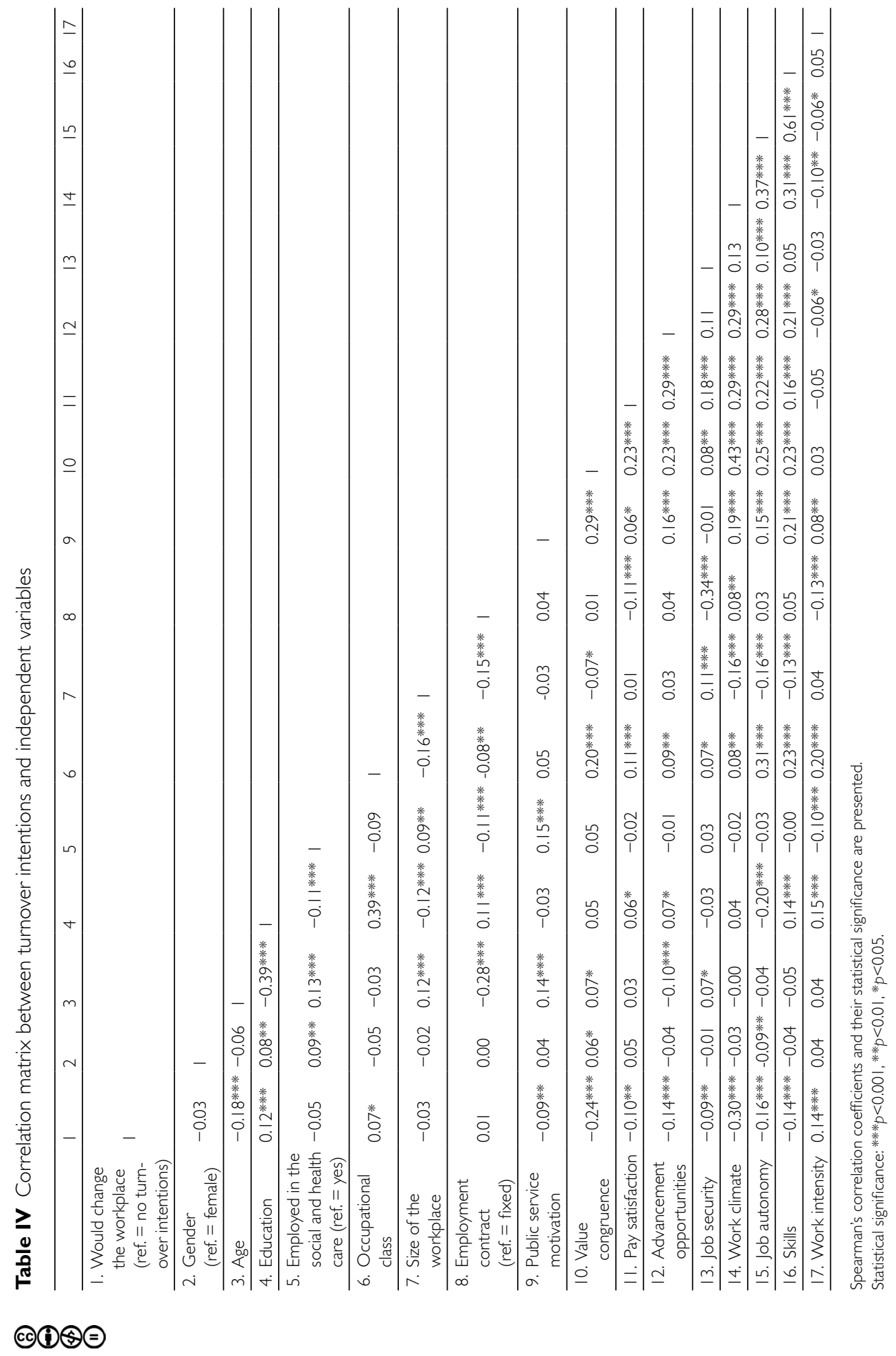

